\title{
PENINGKATAN MEKANISME KOPING PADA PASIEN KANKER PAYUDARA DI RUMAH SAKIT GRANDMED LUBUK PAKAM
}

\section{Tati Murni Karokaro ${ }^{*}$, Rahmad Gurusinga, Dian Anggriyanti, Rosita Ginting, Mila Gustia, Miftahul Zannah ${ }^{2}$, Abdi Lestari Sitepu ${ }^{3}$}

\footnotetext{
${ }^{1}$ Program Studi Keperawatan Program Sarjana, Institut Kesehatan Medistra Lubuk Pakam

${ }^{2}$ Program Studi Pendidikan Profesi Fisioterapis, Institut Kesehatan Medistra Lubuk Pakam

${ }^{3}$ Program Studi Keperawatan Diploma III, Institut Kesehatan Medistra Lubuk Pakam
}

\author{
Jln. Sudirman No.38 Lubuk Pakam, Kabupaten Deli Serdang, \\ Sumatera Utara - Indonesia \\ *email korespondensi author: tatikarokaro612sp@gmail.com
}

\section{DOI $10.35451 /$ jpk.v1i1.749}

\begin{abstract}
Abstrak
Keberhasilan mekanisme koping pada pasien dengan kanker payudara tidak hanya bergantung pada pendeteksian sejak dini, tetapi juga pemahaman akan mekanisme penyebabnya. Dampak Psikologis yang dialami setiap pasien khususnya kanker payudara yang menajalani tindakan pengobatan berbeda-beda tergantung dari segi tingkat keparahan (stadium). Perbedaan sebelum dan sesudah diberikan edukasi dapat mempengaruhi mekanisme koping individu itu sendiri. Kondisi yang dapat menimbulkan kecemasan adalah proses pelaksanaan pengobatan kemoterapi. Tujuan penyuluhan ini dalah untuk mengetahui peningkatan mekanisme koping pada penderita kanker payudara di Rumah Sakit Grandmed Lubuk Pakam. Penyuluhan yang dilakukan untuk melihat peningkatan mekanisme koping yaitu dengan menginformasikan langsung kepada pasien kanker payudara mengenai mekanisme koping dengan edukasi, membagikan leaflet dan melakukan analisis data sebelum dan sesudah diberikan edukasi. Analisis data dilakukan dengan menggunakan uji Paired Sample T-Test dengan tingkat kepercayaan 95\% dan nilai $a=0,05$. Hasil yang diperoleh dari penelitian ini telah menunjukkan adanya perubahan mekanisme koping pasien sebelum dan sesudah diberikan edukasi penerapan mekanisme koping dengan nilai $p$-value $=0,001(a>0,05)$. Kesimpulan, terdapat peningkatan mekanisme koping pada pasien kanker payudara yang dilakukan sesuai dengan standar, bagi institusi kesehatan perlu adanya pengawasan dan penyuluhan kepada masyarakat bahwa pentingnya menjaga kesehatan khususnya pada penderita kanker payudara di Rumah Sakit Grandmed Lubuk Pakam.
\end{abstract}

Kata kunci: Mekanisme koping dan kanker payudara

\begin{abstract}
The success of the coping mechanism for patients breast cancer depends not only on early detection but also an understanding of the mechanisms that cause it. Psychological impact experienced by each patient, especially breast cancer which underwent different treatment depending on the level of severity (stage). The differences before and after being given education can affect the coping mechanism of the individual itself. One of the conditions that can cause anxiety is the process of implementing chemotherapy treatment. This study was purpose to determine the increase in coping mechanisms in breast cancer patients at Grandmed Lubuk Pakam Hospital. Counselling was carried out to see an increase coping mechanisms, directly informing breast cancer patients about coping mechanisms with education, distributing leaflets and analyzing data before and after education. Data analysis was performed using the Paired Sample T-Test with a confidence level of $95 \%$ and a value of $a=$ 0.05. The results obtained from this study have shown a change in the coping mechanism of the patient before and after being given education on the application of
\end{abstract}


Received: 16 June 2021 :: Accepted: 24 June 2021 :: Published: 30 June 2021

the coping mechanism with a $p$-value $=0.001$ ( $a>0.05$ ). In conclusion, there is an increase in coping mechanisms in breast cancer patients who are carried out according to standards, for health institutions there is a need for supervision and counselling to the public about the importance of maintaining health, especially for breast cancer patients at Grandmed Lubuk Pakam Hospital.

Keywords:coping mechanism and breast cancer

\section{Pendahuluan}

Penyakit yang menjadi penyebab utama kematian masyarakat dunia adalah kanker. Dampak Psikologis yang dialami setiap pasien khususnya kanker payudara yang menajalani tindakan pengobatan berbeda-beda tergantung dari segi tingkat keparahan (stadium). Perbedaan dampak ini dapat mempengaruhi mekanisme koping individu itu sendiri. Kanker payudara merupakan peyakit ganas yang dialami oleh wanita ancaman yang serius bagi kaum perempuan. Di Indonesia, masalah kanker payudara menjadi lebih besar yang membutuhan perhatian khusus (Andri, \& Dewi, 2017).

Berdasarkan dari data badan World Health Organisasi (WHO), bahwa penderita kanker meningkat dari 1,4 juta menjadi 12,7 juta. Data yang diambil dari GLOBOCAN, Internasional Agency for Research on Cancer (IARC) diketahui bahwa pada tahun 2015 terdapat 13.067.894 kasus baru dan 7.201.575 angka kematian akibat kanker di seluruh dunia.Tahun 2017, kasus baru43,1 per 100.000 perempuan dan angka kematian sebesar 12.9 per 100.000 perempuan. Di negara Indonesia estimasi insiden sebesar 40,3 per 100.000 perempuan atau 48.998 kasus baru pertahun (Rahayuwati \& Witdiawati, 2017).

Tahun 2014 Prevalensi penyakit kanker di Indonesia memiliki persentase 1,5 per 1000 penduduk sama dengan 430 ribu jiwa dengan rincian berdasarkan provinsi yaitu di Yogyakarta dengan 5,1\%, lalu di jawa tengah dengan $3,1 \%$ di ikuti oleh bali $3 \%$ dan DKI Jakarta serta Bengkulu masing-masing 2,0\%. Insiden kanker payudara di Indonesia menempati urutan teratas dari 10 penyakit kanker pada wanita yaitu 134 per 100.000 penduduk perempuan kanker payudara 40 per 100.000 berdasarkan data informasi rumah sakit (SIDR) tahun 2010 kasus rawat inap kanker payudara 28,7\% (Mannopo, 2016)

Tindakan kemoterapi mengalami depresi, ketakutan dan kecemasan tingkat yang di pengaruhi oleh dua faktor atara lain faktor prediposisi seperti: psiko analitik, pandangan interpersonal pandangan prilaku, kajian keluarga dan kajian biologis sedangkan faktor presipitasi dilihat dari internal dan ekternal yang dapat dikelompokan menjadi dua kategori yaitu ancaman terhadap integritas fisik dan ancaman terhadap sistem diri (Setiawan, 2015)

Dari hasil pengamatan atau observasi yang dilakukan oleh peneliti di RS Grandmed Lubuk Pakam, didapat data bahwa jumlah pasien yang menderita kanker payudara dari bulan september 2019 - Desember 2019 terdapat 30 orang terdiagnosa kanker payudara. Berdasarkan wawancara singkat dengan beberapa pasien yang kebetulan ada 10 orang dan 8 diantaranya mengatakan megalami kecemasan dalam menjalani kemoterapi dan rawat inap di rumah sakit.

\section{Metode}

Penyuluhan dilaksanakan di ruang kemoterapi Rumah Sakit Grandmed, 
Received: 16 June 2021 :: Accepted: 24 June 2021 :: Published: 30 June 2021

sampel yang diambil adalah seluruh pasien yang menderita kanker payudara di Rumah Sakit GrandMed Lubuk Pakam yaitu 30 orang. Penyuluhan yang dilakukan untuk melihat peningkatan mekanisme koping yaitu dengan menginformasikan langsung kepada pasien kanker payudara mengenai mekanisme koping dengan edukasi, membagikan leaflet dan melakukan analisis data sebelum dan sesudah diberikan edukasi. Pasien yang menjadi sasaran penyuluhan ini merupakan pasien kanker payudara yang rawat jalan dan pasien yang menjalani kemoterapi.

\section{Hasil dan Pembahasan}

Dari Tabel 1 dan 2 ditampilkan data mekanisme koping pasien kanker payudara di rumah sakit GrandMed Lubuk Pakam sebanyak 30 orang sebelum dan sesudah penyuluhan.

Tabel 1. Mekanisme Koping pada pasien kanker payudara sebelum diberikan edukasi di Rumah Sakit Grandmed Lubuk Pakam Tahun 2020.

\begin{tabular}{ccccc}
\hline $\begin{array}{c}\text { Mekanisme } \\
\text { koping }\end{array}$ & Mean & $\mathrm{n}$ & $\begin{array}{c}\text { Std. } \\
\text { Deviation }\end{array}$ & $\begin{array}{c}\text { Std. Error } \\
\text { Mean }\end{array}$ \\
\hline sebelum & 1,60 & 30 &, 498 &, 091 \\
\hline
\end{tabular}

Tabel 2 Mekanisme Koping pada pasien kanker payudara sesudah diberikan edukasi di Rumah Sakit Grandmed Lubuk Pakam Tahun 2020.

\begin{tabular}{ccccc}
\hline $\begin{array}{c}\text { Mekanisme } \\
\text { koping }\end{array}$ & Mean & $\mathrm{N}$ & $\begin{array}{c}\text { Std. } \\
\text { Deviation }\end{array}$ & $\begin{array}{c}\text { Std. } \\
\text { Error } \\
\text { Mean }\end{array}$ \\
\hline Sesudah & 1,97 & 30 &, 183 &, 033 \\
\hline
\end{tabular}

Tabel 3 Mekanisme koping sebelum dan sesudah diberikan edukasi pada pasien kanker payudara di Rumah Sakit Grandmed Lubuk Pakam Tahun 2020

\begin{tabular}{cccccc}
\hline $\begin{array}{c}\text { Edukasi } \\
\text { mekanisme } \\
\text { koping }\end{array}$ & $\begin{array}{c}\text { Rata- } \\
\text { rata }\end{array}$ & $\begin{array}{c}\text { Standar } \\
\text { Deviasi }\end{array}$ & $\begin{array}{c}\text { Standar } \\
\text { Eror }\end{array}$ & pValue & $\mathbf{n}$ \\
\hline Pre test & 1.60 & 489 & 0,091 & 0,001 & 30
\end{tabular}

$\begin{array}{llllll}\text { Post test } & 1.90 & 183 & 0,033 & 0,001 & 30\end{array}$

Berdasarkan hasil uji statistik dengan menggunakan uji dependent sample $t$ test /paired $t$ test menunjukkan bahwa pValue yaitu 0.001 yang berarti pValue $\leq$ dari 0.05. Maka hipotesa diterima yang berarti terdapat pengaruh yang signifikan terhadap mekanisme koping pada pasien kanker payudara. Berdasarkan hasil uji statistik dengan menggunakan uji paired t-test menunjukkan bahwa rerata tingkat kecemasan sebelum diberikan mekanisme koping yaitu 1.60 , rerata peningkatan mekanisme kopingsebelum dan sesudah edukasi.Hal tersebut menunjukkan bahwa terdapat pengaruh antara sebelum dan sesudah dilakukan pemberian mekanisme koping.

Tabel 4 Rata-rata, Standart Deviasi, Lower, Upper, $p$ Value

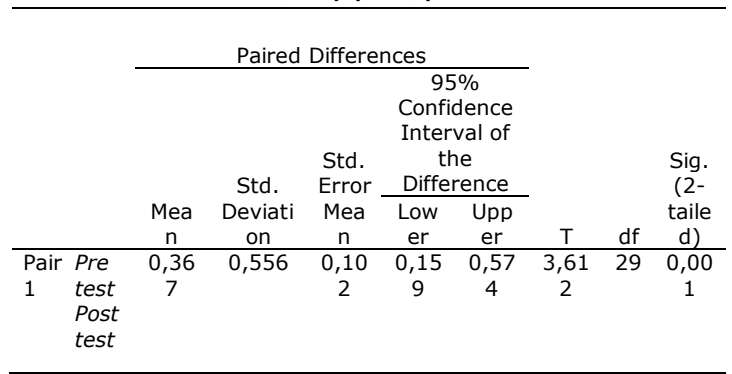

$\begin{array}{ccc}\text { Mekanisme } & \text { koping adaptif } \\ \text { dibandingkan mekanisme koping }\end{array}$ maladaptive didapatkan responden sebanyak 59 orang terdapat $61 \%$ pasien kanker menggunakan mekanisme koping adaptif dan 39\% pasien kanker menggunakan mekanisme koping maladaptif. Hal ini dipicu oleh sedikitnya angka kejadian ansietas/depresi yang dialami oleh pasien kanker sehingga lebih banyak pasien menggunakan mekanisme koping adaptif. Koping strategi seharusnya dapat dikendalikan secara personal, akan tetapi lingkungan sosial dapat pula mempengaruhi koping secara individu. Pada penelitian ini, 
Received: 16 June 2021 :: Accepted: 24 June 2021 :: Published: 30 June 2021

pasien menilai penyakit kanker merupakan suatu tantangan atau ancaman sehingga pasien tidak dapat mengendalikan situasi dengan baik sehingga lebih banyak menggunakan mekanisme koping maladaptif dibandingkan dengan pasien yang menggunakan mekanisme koping adaptif (Gina, 2014; siswanto, 2007; Carver \& Connor-smith, 2010).

Pada penelitian lain, responden menganggap penyakit kanker suatu ancaman yang wajar sehingga responden masih mampu mengatasi penyakit yang dideritanya. Hal tersebut didukung dari hasil penelitian yaitu lebih dari separuh pasien menggunakan mekanisme koping adaptif sehingga pasien dapat mengatasi penyakitnya dengan cara yang lebih baik dibandingkan dengan pasien yang menggunakan mekanisme koping maladaptif. Dari hasil diatas dapat disimpulkan bahwa setelah diberikan perlakuan mekanisme koping akan menghasilkan hasil yang lebih baik dibanding sebelum diberi perlakuan mekanisme koping. Hal ini dapat di asumsikan terjadi peningkatan ke arah yang lebih baik tentang hasil setelah diberi perlakuan mekanisme koping dibanding sebelum mendapat mekanisme koping.

Pada penelitian ini, gejala fisiologis yang ditimbulkan tidak menimbulkan penderitaan yang bermakna bagi pasien kanker yang menjalani kemoterapi. Hal ini disebabkan oleh pasien yang terkena penyakit kanker lebih berfokus kepada pekerjaan lain yang dapat membuat pasien mengalihkan rasa cemasnya. Pasien kanker mengalami kecemasan berat dikarenakan ketakutan yang berlebihan akan adanya perubahan fisik, psikologis serta takut akan terjadinya kematian (Setiawan, 2015)

Pasien yang mengalami penurunan mekanisme koping akan berusaha untuk mencari simpati dari orang lain dan sekitarnya, mengganggap masalah yang dihadapi memiliki manfaat bagi dirinya dan menjadikan individu menjadi lebih baik, kondisi yang di hadapi pasien Ini adalah penyakit yang tidak dapat dihindari, dan semakin banyak ibadah yang Anda miliki, semakin besar ketaatan dan kepercayaan Anda kepada Tuhan. Ini karena menyerah menurunkan tingkat stres yang dapat mempengaruhi perkembangan kanker, dan pasien terkadang menyangkal bahwa itu terjadi sesuai dengan keyakinannya. , Tidak masalah. (Thompson, 2015).

Penolakan hanya akan menimbulkan lebih banyak masalah. Singkatnya, menyangkal atau menyangkal fakta dapat menyebabkan masalah yang lebih serius yang mempersulit pengobatan dan memperburuk penyakit. Pasien emosional selalu berusaha untuk mengontrol reaksi emosional yang mereka rasakan. Studi ini menunjukkan bahwa $28,6 \%$ pasien menggunakan mekanisme koping emosional yang berorientasi pada masalah. Koordinasi keduanya secara langsung memungkinkan individu untuk memiliki beberapa resolusi konflik atau mekanisme koping yang dapat beradaptasi dengan tingkat stres yang mereka hadapi. Koping yang berorientasi emosi menuntaskan pertarungan atau masalah dengan cara mencari dukungan sosial, reinterpretasi positif, penerimaan, penolakan dan beribadah. Penggunaan koping berfokus dalam emosi olehindividu dipakai buat mengatasi emosi negatif dimana taktik tersebut tidak membarui situasi stres, namun hanya mengubah cara individu mengahayati atau memikirkan situasi (Tasripiyah, Prawesti, and Rahayu n.d.). Koping yang adaptif juga menentukan kepatuhan menjalani kemoterapi pada pasien kanker.Koping yang baik akan mengakibatkan 
Received: 16 June 2021 :: Accepted: 24 June 2021 :: Published: 30 June 2021

kepatuhan dalam mengikuti terapi akan semakin patuh, meskipun mekanisme koping tidak menentukan prevalensi terjadinya kejadian kanker(Sonia, Arifin, and Murni 2014; Surtees, 2010).

Diketahui nilai $t$ saat diberikan mekanisme koping pada pasien penderita Kanker Payudara adalah 3,612 dengan problablitas (sig) $0,000<$ 0,001 maka Ho ditolak. Artinya terdapat pengaruh pemberian mekanisme koping pada pasien penderita kanker payudara di Rumah Sakit Grandmed Lubuk Pakam. Dari hasil diatas dapat disimpulkan bahwa sebelum dan setelah diberikan edukasi mekanisme koping akan didapati perubahan mekanisme koping. Hal ini dapat di asumsikan terjadi peningkatan kearah yang lebih baik tentang hasil setelah diberi perlakuan mekanisme koping dibanding sebelum mendapat tindakan mekanisme koping maka $\mathrm{Ho}$ diterima dan $\mathrm{Ha}$ ditolak.

\section{Kesimpulan}

Peningkatan mekanisme koping pada 30 pasien kanker payudara sebelum dan sesudah dilakukan penyuluhan mekanisme koping memiliki rata-rata 1,60 dengan Standart Deviasi (SD) 489 dan rata-rata 1,90 dengan Standart Deviasi (SD) 183. Dari hasil penyuluhan didapatkan nilai $p$ Value $=0,001$ dengan nilai Tingkat kecemasan rata-rata sebelum dan sesudah dilakukan pemberian mekanisme koping 0,637 dengan Standart Deviasi (SD) 0,556.

Kelebihan dari pengabdian masyarakat yang dilakukan pada pasien kanker payudara di Rumah Sakit Grandmed Lubuk Pakam yaitu dapat meningkatkan mekanisme koping pasien kanker payudara dan kekurangannya yaitu memerlukan waktu yang panjang untuk melatih pasien kanker payudara unutk mendapatkan peningkatan mekanisme koping.

\section{Ucapan Terima Kasih}

Ucapan terima kasih disampaikan kepada Insitut Kesehatan Medistra Lubuk Pakam dan Rumah Sakit Grandmed Lubuk Pakam yang membantu pendanaandalam melaksanakan proses pengabdian masyarakat.

\section{Daftar Pustaka}

Andri, \& Yenny Dewi, P. (2017). Teori kecemasan berdasarkan psikoanalisis klasik dan berbagai mekanisme pertahanan terhadap kecemasan. Majalah Kedokteran Indonesia.

Astuti, N. M., Sustrami, D., Hastuti, P., Nurlela, L., \& Herningtiyas A.N, F. (2019). Karakteristik Mekanisme Koping Pasien Kanker Payudara di Poli Bedah Onkologi Rumkital Dr. Ramelan Surabaya. Jurnal IImiah Keperawatan Stikes Hang Tuah Surbaya. https://doi.org/10.30643/jiksht.v1 $3 \mathrm{i} 1.23$

Aziz, A. H. (2017). Metodologi Penelitian Keperawatan dan Kesehatan. In salemba medika.

Diyono, \& Mulyanti, S. (2013). Keperawatan Medikal Bedah: Buku Ajar. In Keperawatan Medikal Bedah: Buku Ajar.

Gambaran Kualitas Hidup Pada Wanita Dewasa Awal Penderita Kanker Payudara. (2019). Psikologia: Jurnal Pemikiran Dan Penelitian Psikologi. https://doi.org/10.32734/psikologi a.v13i3.24633

Goyena, R. (2019). Faktor Yang Mempengaruhi Kualitas Hidup Pasien Kanker Payudara Di Rsup Dr M Djamil Padang Tahun 201. Journal of Chemical Information and Modeling. https://doi.org/10.1017/CB09781 107415324.004

Haryati, \& Sitorus, R. (2015). Pengaruh Latihan Progressive Muscle Relaxation Terhadap Status 
Received: 16 June 2021 :: Accepted: 24 June 2021 :: Published: 30 June 2021

Fungsional Dalam Konteks Asuhan Keperawatan Pasien Kanker dengan Kemoterapi di RS Dr.Wahidin Sudirohusodo Makassar. Medula.

Komite Penanggulangan Kanker Nasional. (2015). Panduan Penatalaksanaan Kanker Payudara. Kementerian Kesehatan Republik Indonesia. https://doi.org/10.1111/evo.1299 0

M, M. S. (2018). Pengalaman Masa Lalu, Kondisi Kesehatan Fisik, Konsep Diri dan Dukungan Sosial terhadap Mekanisme Koping. Jurnal IImiah Kebidanan Indonesia. https://doi.org/10.33221/jiki.v8i0 2.150

Mannopo, I. J. (2016). Hubungan paritas dan usia ibu dengan kanker serviks di rsu prof. kandou manado tahun 2014. Jurnal Skolastik Keperawatan.

Mardiana, D., Ma'rifah, A. R., \& Rahmawati, A. N. (2013). Hubungan mekanisme koping dengan kualitas hidup penderita kanker servik di RSUD Prof. dr. Margono Soekarjo Purwokerto. Jurnal Keperawatan Maternitas.

Mubarak, W. I., Indrawati, L., \& Susanto, J. (2015). Buku Ajar Ilmu Keperawatan Dasar. In Buku 1. https://doi.org/10.1111/ecoj.1242 6

Mulyani, N. S. (2013). Kanker Payudara dan PMS pada Kehamilan. Jakarta: Nuha Medika. https://doi.org/10.1117/12.47439 $\underline{9}$

Notoatmodjo, S. (2012). Metodologi Penelitian Ilmu Keperawatan. In Jakarta: Salemba Merdeka.

Nurarif, A. H., \& Kusuma, H. (2015). Aplikasi asuhan keperawatan berdasarkan diagnosa medis \&NANDA. In trjectoriesof sleep quality and mood in the perinatal

Nursalam. (2015). Metodologi Penelitian Ilmu Keperawatan:Pendekatan Praktis. In Salemba Medika. period. $\quad$ https://doi.org/978-60272002-2-7

Rahayuwati, L., Sari, S. P., \& Witdiawati. (2017). Studi kualitatif pola kehidupan pasien kanker payudara A Qualitative Study on Breast Cancer Patients Life. Journal Nursing Padjajaran.

Rahma, K. (2020). TERAPI KOGNITIF : SELF HELP GROUP PADA PASIEN KANKER PAYUDARA. National Nursing Conference. https://doi.org/10.34305/nnc.v1i1 .117

Setiawan, D. (2015). the Effect of Chemotherapy in Cancer Patient To Anxiety. Jurnal Majority.

Smeltzer, S. C \& Barre, B. G. (2017). Buku ajar keperawatan medikalbedah Brunner \& Suddarth. Journal of Chemical Information and Modeling. https://doi.org/10.1017/CBO9781 107415324.004

Thompson, E. (2015). Hamilton rating scale for anxiety (HAM-A). In Occupational Medicine. https://doi.org/10.1093/occmed/k qv054

Utami, S. S., \& Mustikasari, M. (2017). Aspek Psikososial Pada Penderita Kanker Payudara: Studi Pendahuluan. Jurnal Keperawatan Indonesia. https://doi.org/10.7454/jki.v20i2. 503

Wijayanto, T. (2017) Pendidikan Kesehatan Terhadap Tingkat Kecemasan Pada Pasien Preoperasi Kanker Payudara. Jurnal IImiah Kesehatan. https://doi.org/10.35952/jik.v6i1. $\underline{84}$ 